MATEC Web of Conferences 6, 00001 (2013)

DOI: $10.1051 /$ matecconf/20130600001

(C) Owned by the authors, published by EDP Sciences, 2013

\title{
To the memory of Prof. Ulrich Schneider
}

The 3rd International Workshop on Concrete Spalling due to Fire Exposure and these proceedings are dedicated to the memory of Prof. Ulrich Schneider. Ulrich was the chairman of the RILEM HPB Technical Committee. He mapped out our path and shared with us his impressive deep and extensive scientific expertise and his human value. He has left to the scientific community an immense and rich heritage.

This is an Open Access article distributed under the terms of the Creative Commons Attribution License 2.0, which permits unrestricted use, distribution, and reproduction in any medium, provided the original work is properly cited. 